\title{
PHYSICAL-MECHANICAL PROPERTIES OF BRIQUETTES PRODUCED FROM CHARCOAL FINES AND WASTE OF Pinus spp.
}

\author{
André Tarcizo de Oliveira Vieira ${ }^{1 *}$, Alexandre Miguel do Nascimento², Azarias Machado de Andrade², \\ Ananias Francisco Dias Júnior ${ }^{* *}$ \\ $1^{*}$ National Steel Company - CSN S/A, Volta Redonda, Rio de Janeiro, Brazil - andretarcizo@yahoo.com.br \\ ${ }^{2}$ Federal University of Rural Rio de Janeiro, Forest Products Department - DPF/UFRRJ, Seropédica, Rio de Janeiro, Brazil - \\ alexmnasci@gmail.com; azarias@ufrrj.br \\ ${ }^{3}$ Federal University of Espírito Santo, Forest Science and Wood Department - DCFM/UFES, Jerônimo Monteiro, \\ Espírito Santo, Brazil - ananiasjr@usp.br
}

Received for publication: 01/09/2017 - Accepted for publication: 14/05/2018

\begin{abstract}
The objective of this research was to evaluate the physical and mechanical properties of briquettes produced with charcoal fines and waste of Pinus spp (sawdust and wood shavings). For the production, the charcoal fines of two particle sizes (less than and greater than $5 \mathrm{~mm}$ ) were mixed with each type of wood waste of Pinus spp in the proportions of 5, 10, 15, and 20\%. Then, the mixtures were compacted under the pressure of $55 \mathrm{kgf.cm}{ }^{-2}$ in a piston briquetter. As binder, $8 \%$ gelatinized maize starch was used. Tests were carried out on the briquettes in order to determine the apparent density, compressive strength, and friability index. Briquettes with the highest densities and compressive strengths were produced with the two lowest proportions of wood waste of Pinus spp (5 and 10\%). The use of the charcoal fines combined with sawdust or wood shavings of Pinus spp is recommended for the production of briquettes with good physical and mechanical properties. Keywords: Biomass and bioenergy, compression and friability, use of forest residues.
\end{abstract}

\section{Resumo}

Propriedades físico-mecânicas de briquetes produzidos de moinha de carvão e resíduos de Pinus spp. O objetivo desta pesquisa foi avaliar as propriedades físicas e mecânicas de briquetes produzidos com moinha de carvão vegetal, consorciada com resíduos da madeira de Pinus spp (serragem e maravalha). Para produção, a moinha de carvão vegetal, com duas granulometrias (menor e maior que $5 \mathrm{~mm}$ ), foi misturada a cada tipo de resíduo da madeira de Pinus spp nas proporções de 5, 10, 15 e 20\%. Em seguida, as misturas foram compactadas sob pressão de $55 \mathrm{kgf.cm}{ }^{-2} \mathrm{em}$ uma briquetadeira de pistão. Como aglutinante, utilizou-se o amido de milho gelatinizado a $8 \%$. Os briquetes foram submetidos a ensaios para a determinação da massa específica aparente, resistência à compressão e índice de friabilidade. As maiores massas específicas e resistências à compressão foram observadas nos briquetes produzidos com as duas menores proporções de resíduos da madeira de Pinus spp (5 e 10\%). Diante do exposto, recomenda-se a utilização da moinha de carvão vegetal, consorciada com serragem ou maravalha de Pinus spp, para a produção de briquetes com melhores propriedades físicas e mecânicas.

Palavras-chave: Biomassa e bioenergia, compressão e friabilidade, aproveitamento de resíduos florestais.

\section{INTRODUCTION}

Brazil is at the same time the largest producer and the largest consumer of charcoal in the world. Estimates indicate that during the year 2016, approximately 6.0 million tons of this input were produced, almost all the product sent to the steel sector (BRAZIL, 2017). Although it is an excellent fuel of wide application, some characteristics and properties of charcoal are unfavorable for some uses, such as its low density and high friability. In the production process and handling of the charcoal, from the carbonization furnaces to its final use, a large quantity of fines is generated.

In the production, transport, handling, and sieving phases, coal generates a quantity of fines that can reach $25 \%$ of the total produced (SANTIAGO; ANDRADE, 2005). In steelmaking, for example, the processes for meeting the grain size specifications of modern blast furnaces may also generate additional fines. Generally, only part of the fines is used for steel purposes by injection into the windows as an auxiliary fuel. The surplus is destined for other industries, such as cement, pharmaceutical, food, and the production of flowers, among other uses.

By compacting mechanisms, briquetting (agglomeration of particles of lesser size by means of pressure, with or without the use of an organic or inorganic binder) can produce a high-quality fuel with density, shape, dimension, moisture, chemical composition, and standardized mechanical properties (PEREIRA et al., 2009; KALIYAN; MOREY, 2010; QUIRINO et al., 2012; DIAS JÚNIOR et al., 2014. As an alternative, briquetting can be extended to applications that aim to reuse other industrial wastes, such as peat, various biomasses, plastics, and metal filings (PROTÁSIO et al., 2012; DIAS JÚNIOR et al., 2016; MARTINS et al., 2016).

FLORESTA, Curitiba, PR, v. 48, n. 4, p. 513-522, out/dez. 2018

Vieira. A. T. O. et.al.

ISSN eletrônico 1982-4688

DOI: $10.5380 /$ rf.v48i4.55028 
In evaluation of the briquettes properties, the most common tests aiming at the suitability for final use are carried out to determine the apparent specific mass, impact strength, compressive strength (burst load), abrasion resistance and drum resistance to the penetration of water (hygroscopicity), and calorific value (QUIRINO et al., 2012). The tests of combustibility and rate of burning are more common in the case of domestic use, for cooking food (QUIRINO; BRITO, 1991, DIAS JÚNIOR et al., 2014, DIAS JÚNIOR et al., 2016).

There is also very great potential for application of briquetting in forest-based industries. Generally, the companies of this sector present low yield and generate large amounts of waste during the processing of the wood, mainly, those originating from processing. Residues generated in the form of clods, shavings, bark, sawdust, brushwood, and shavings can represent $51 \%$ of the original log volume (BOASIAKO; ACHEAMPONG, 2016). The inadequate storage of these wastes, without proper disposal, generates serious environmental problems, such as silting of rivers and ponds, as well as the risk of fire and air pollution due to open burning (BRAND, 2010; PROTASIO et al., 2011). It is, therefore, necessary to determine better uses for such waste, which can lead to significant environmental problems. These wastes are an interesting raw material to be used in various applications, such as in the generation of thermal energy for various industrial segments.

On the other hand, Brazil does not yet have an industrial tradition of producing charcoal briquettes (COELHO JÚNIOR et al., 2013). There is great consumer resistance to use of this product as a substitute for charcoal, due to its combustion characteristics, greater ignition difficulty, less flame generation during the combustion, and apparent formation of a larger volume of ash (BOASIAKO; ACHEAMPONG, 2016). With respect to the production of charcoal briquettes for meeting the commercial demand of the domestic segment in Brazil, little has been done at the laboratory and industrial scales. However, the main use of charcoal briquettes produced abroad, especially in Europe, are made in this sector (BOASIAKO; ACHEAMPONG, 2016).

Nowadays, Brazilian production is boiled down to the pioneering and isolated activities of small and mediumsized producers, who, despite their merit, are generally unable to achieve the qualities demanded by the consumer market. In addition, they do not reach production and marketing levels observed in other countries. This activity could solve the shortage of "clean" fuels, presenting more affordable prices for mainly domestic use (BAMGBOYE; BOLUFAWI, 2009; QUIRINO et al., 2012; BOASIAKO; ACHEAMPONG, 2016; WANG et al., 2017). Thus, it is hypothesized that the use of charcoal fines mixed with wood residues of Pinus spp in different particle sizes, can result in briquettes with good physical-mechanical characteristics to meet the demand of several industrial sectors.

The objective of this study was to evaluate the physical and mechanical properties of briquettes produced when mixing charcoal fines with sawdust and shavings of Pinus spp in four different proportions.

\section{MATERIAL AND METHODS}

\section{Raw Material}

Approximately four tons of charcoal grinder that were generated after successive carbonizations of Eucalyptus spp wood were made available by Carvalho ME Ltda, located in the municipality of Barra Mansa in the state of Rio de Janeiro. The fines were packed in polypropylene bags of $30 \mathrm{~kg}$ capacity and transported to the briquetting unit. The material was classified in a $5 \mathrm{~mm}$ square mesh sieve to obtain two fractions: one above $5 \mathrm{~mm}$ and the other one below $5 \mathrm{~mm}$. It should be noted this is the cutting mesh used by the steel industry in the processing of charcoal. The crude fines composite was submitted to a sequence of sieves until a representative sample was obtained for the determination of the particle size distribution.

Regarding wood residues of Pinus spp (shavings and sawdust), two tons were collected from a company of unfolding and commercialization of improved wood, located in the municipality of Barra Mansa.

\section{Composition and production of briquettes}

The wood waste of Pinus spp, in the proportions of 5, 10, 15, and 20\%, was mixed with the charcoal fines and binder $(\mathrm{m} / \mathrm{m})$. The binder used was $8 \%$ gelatinized maize starch. The materials were homogenized in a 60-liter intensive mixer and then packed in an endless screw briquetting machine under pressure of $55 \mathrm{kgf.cm}{ }^{-2}$. The compression system was continuous at a speed of $800 \mathrm{rpm}$, capable of producing briquettes of $73 \mathrm{~mm}$ in diameter and $100 \mathrm{~mm}$ in length. The briquettes were dried in an oven with forced air circulation at $110{ }^{\circ} \mathrm{C}$. Table 1 shows the composition of the briquettes that were evaluated in this study. 
Table 1. Composition of the briquettes under the conditions set out in 16 treatments.

Tabela 1. Composição dos briquetes sob as condições estabelecidas em 16 tratamentos.

\begin{tabular}{|c|c|c|c|c|}
\hline \multirow{3}{*}{$\begin{array}{c}\text { Waste } \\
\text { Pinus } \operatorname{spp}(\%)\end{array}$} & \multicolumn{4}{|c|}{ Particle sizes of charcoal fines } \\
\hline & \multicolumn{2}{|c|}{$<5 \mathrm{~mm}$} & \multicolumn{2}{|c|}{$>5 \mathrm{~mm}$} \\
\hline & Sawdust & Shavings & Sawdust & Shavings \\
\hline 5 & $\mathrm{~T} 1$ & $\mathrm{~T} 2$ & T9 & $\mathrm{T} 10$ \\
\hline 10 & $\mathrm{~T} 3$ & $\mathrm{~T} 4$ & $\mathrm{~T} 11$ & $\mathrm{~T} 12$ \\
\hline 15 & $\mathrm{~T} 5$ & T6 & $\mathrm{T} 13$ & $\mathrm{~T} 14$ \\
\hline 20 & $\mathrm{~T} 7$ & $\mathrm{~T} 8$ & $\mathrm{~T} 15$ & T16 \\
\hline
\end{tabular}

In which: Binder: $8 \%$ gelatinized maize starch; and T: treatment analyzed.

\section{Physical and mechanical tests of briquettes produced}

The physical and mechanical tests of the briquettes were carried out in the laboratories of National Steel Company (CSN) and Cimento Rio Branco S/A, both located in the city of Volta Redonda (state of Rio de Janeiro, Brazil).

The equilibrium moisture was obtained by the gravimetric method, as described in standard NBR 8293 (ABNT, 1983). The apparent specific mass of the briquette $\left(\mathrm{g}_{\mathrm{cm}} \mathrm{cm}^{-3}\right)$ was determined according to standard NBR 9165 (ABNT, 1982). The briquette was weighed, and then, its volume was estimated by the hydrostatic method that is based on the displacement of a mass of water inside a container placed on the plate of a precision scale and caused by immersion of a body in the water, according to the principle of Archimedes.

The compressive strength $\left(\mathrm{kgf} . \mathrm{cm}^{-2}\right)$ was determined to evaluate the mechanical behavior of the briquettes when subjected to a given load or effort. The load test was performed using a universal test machine from the Instron brand. The load was applied in the longitudinal direction of the briquettes with dimensions of $50 \mathrm{~mm}$ in length and $40 \mathrm{~mm}$ in diameter. Before the tests, the briquettes were placed in a mold and sanded in the perpendicular and transverse directions, until the pre-established dimensions were reached. The methodology used reproduced the procedures described by Paula et al. (2011).

The friability of the briquettes, based on the abrasion resistance, was determined using a rotary drum that had two diametrically opposed sides that were $50 \mathrm{~mm}$ wide on its inner sides to simulate the fall effect. The drum was rotated at $15 \mathrm{rpm}$ for a period of 10 minutes. The friability of the briquettes was determined after the classification of the material submitted to the drum by a $5 \mathrm{~mm}$ square mesh sieve, in accordance with the procedures described in standard NBR 8629 (ABNT, 1984).

\section{Experimental design and statistical analysis of data}

The experimental design was the completely randomized factorial. The effects of the average particle size of the charcoal fines (>5 mm and $<5 \mathrm{~mm}$ ), the two types of wood residues of Pinus spp (sawdust and shavings), and the four proportions of the residues in the briquettes composition $(5,10,15$, and $20 \%)$ were all analyzed. Thus, 16 treatments, with 10 replicates each, were completed.

Before the analysis of variance (ANAVA), the normality of the variables dependent on the KolmogorrovSmirnov test and the homogeneity of the variances by the Levene test were verified at a 95\% probability level. Based on these assumptions, the dependent variables were submitted to ANAVA and analyzed by the F test. When significant, the Tukey test was applied to compare the means of the treatments. When the variables did not fit a normal distribution or presented non-homogeneous variances, the non-parametric Kruskal-Wallis and Mann Whitney tests were applied.

\section{RESULTS}

Table 2 shows the average values of the apparent specific masses of the briquettes, produced according to the pre-established treatments.

FLORESTA, Curitiba, PR, v. 48, n. 4, p. 513-522, out/dez. 2018

Vieira. A. T. O. et.al. 
Table 2. Apparent density of the briquettes produced.

Tabela 2. Massa específica aparente dos briquetes produzidos.

\begin{tabular}{|c|c|c|c|c|c|}
\hline \multirow{4}{*}{$\begin{array}{c}\text { Waste Pinus spp } \\
(\%)\end{array}$} & \multirow{2}{*}{\multicolumn{4}{|c|}{ Apparent specific briquette mass $\left(\mathrm{g} . \mathrm{cm}^{-3}\right)$}} & \multirow{4}{*}{ Mean } \\
\hline & \multicolumn{3}{|c|}{ Particle sizes of charcoal fines(mm) } & & \\
\hline & \multicolumn{2}{|c|}{$<5 \mathrm{~mm}$} & \multicolumn{2}{|c|}{$>5 \mathrm{~mm}$} & \\
\hline & Sawdust & Shavings & Sawdust & Shavings & \\
\hline 5 & $0.67^{\mathrm{cB}}$ & $0.81^{\mathrm{aA}}$ & $0.83^{\mathrm{aA}}$ & $0.78^{\mathrm{aA}}$ & $0.78^{\mathrm{a}}$ \\
\hline 10 & $0.80^{\mathrm{aA}}$ & $0.76^{\mathrm{abA}}$ & $0.78^{\mathrm{aA}}$ & $0.75^{\mathrm{abA}}$ & $0.77^{\mathrm{a}}$ \\
\hline 15 & $0.76^{\mathrm{abA}}$ & $0.75^{\mathrm{abAB}}$ & $0.75^{\mathrm{aAB}}$ & $0.70^{\mathrm{abcB}}$ & $0.74^{\mathrm{b}}$ \\
\hline 20 & $0.69^{\mathrm{cAB}}$ & $0.71^{\mathrm{bAB}}$ & $0.75^{\mathrm{aA}}$ & $0.65^{\mathrm{cAB}}$ & $0.70^{\mathrm{c}}$ \\
\hline Mean & $0.73^{\mathrm{BC}}$ & $0.76^{\mathrm{AB}}$ & $0.78^{\mathrm{A}}$ & $0.72^{\mathrm{C}}$ & \\
\hline Mean & \multicolumn{2}{|c|}{$0.75^{\mathrm{A}}$} & \multicolumn{2}{|c|}{$0.75^{\mathrm{A}}$} & \\
\hline
\end{tabular}

Different lowercase and uppercase letters show, respectively, significant differences between the means in the columns and in the rows by the Tukey test to $95 \%$ of probability.

According to Table 2, it can be observed that the apparent specific mass of the briquettes varied according to the proportion of the residues of the Pinus spp wood used. In Table 3, it can be seen that there was a tendency to reduce the average resistance to compression as the proportion of Pinus spp residues in the briquettes composition decreased, except for the treatment in which 5\% sawdust was included in the charcoal grinder with a mean grain size of $<5 \mathrm{~mm}$.

Table 3. Resistance of the briquettes to compression according to the proportion of wood waste of Pinus spp and the average particle sizes of the charcoal fines.

Tabela 3. Resistência dos briquetes à compressão em função da proporção de resíduos da madeira de Pinus spp e da granulometria média da moinha de carvão vegetal.

\begin{tabular}{|c|c|c|c|c|c|}
\hline \multirow{4}{*}{$\begin{array}{l}\text { Waste Pinus } \\
\text { spp }(\%)\end{array}$} & \multirow{2}{*}{\multicolumn{4}{|c|}{$\begin{array}{c}\text { Resistance of briquettes to compression }\left(\mathrm{kgf}^{\left.-\mathrm{cm}^{-2}\right)}\right. \\
\text { Particle sizes of charcoal fines }(\mathrm{mm})\end{array}$}} & \multirow{4}{*}{ Mean } \\
\hline & & ticle sizes o & arcoal fine & & \\
\hline & \multicolumn{2}{|c|}{$<5 \mathrm{~mm}$} & \multicolumn{2}{|c|}{$>5 \mathrm{~mm}$} & \\
\hline & Sawdust & Shavings & Sawdust & Shavings & \\
\hline 5 & $4.6^{\mathrm{bB}}$ & $9.0^{\mathrm{aA}}$ & $10.4^{\mathrm{aA}}$ & $8.4^{\mathrm{aA}}$ & $8.1^{\mathrm{ab}}$ \\
\hline 10 & $9.4^{\mathrm{aA}}$ & $9.4^{\mathrm{aA}}$ & $9.0^{\mathrm{aAB}}$ & $8.6^{\mathrm{aA}}$ & $9.1^{\mathrm{a}}$ \\
\hline 15 & $9.0^{\mathrm{aA}}$ & $7.6^{\mathrm{aAB}}$ & $8.0^{\mathrm{aAB}}$ & $6.6^{\mathrm{aAB}}$ & $7.8^{\mathrm{b}}$ \\
\hline 20 & $5.0^{\mathrm{aB}}$ & $5.2^{\mathrm{aB}}$ & $6.2^{\mathrm{aB}}$ & $5.0^{\mathrm{aB}}$ & $5.4^{\mathrm{c}}$ \\
\hline Mean & $7.0^{\mathrm{B}}$ & $7.8^{\mathrm{AB}}$ & $8.4^{\mathrm{A}}$ & $7.2^{\mathrm{B}}$ & \\
\hline Mean & \multicolumn{2}{|c|}{$7.4^{\mathrm{A}}$} & \multicolumn{2}{|c|}{$7.8^{\mathrm{A}}$} & \\
\hline
\end{tabular}

Different lowercase and uppercase letters show, respectively, significant differences between the means in the columns and in the rows by the Tukey test to $95 \%$ of probability.

Figures 1 and 2 present the results of the apparent specific mass and compressive strength of the briquettes, as well as their respective comparisons and variations between the analyzed treatments. 

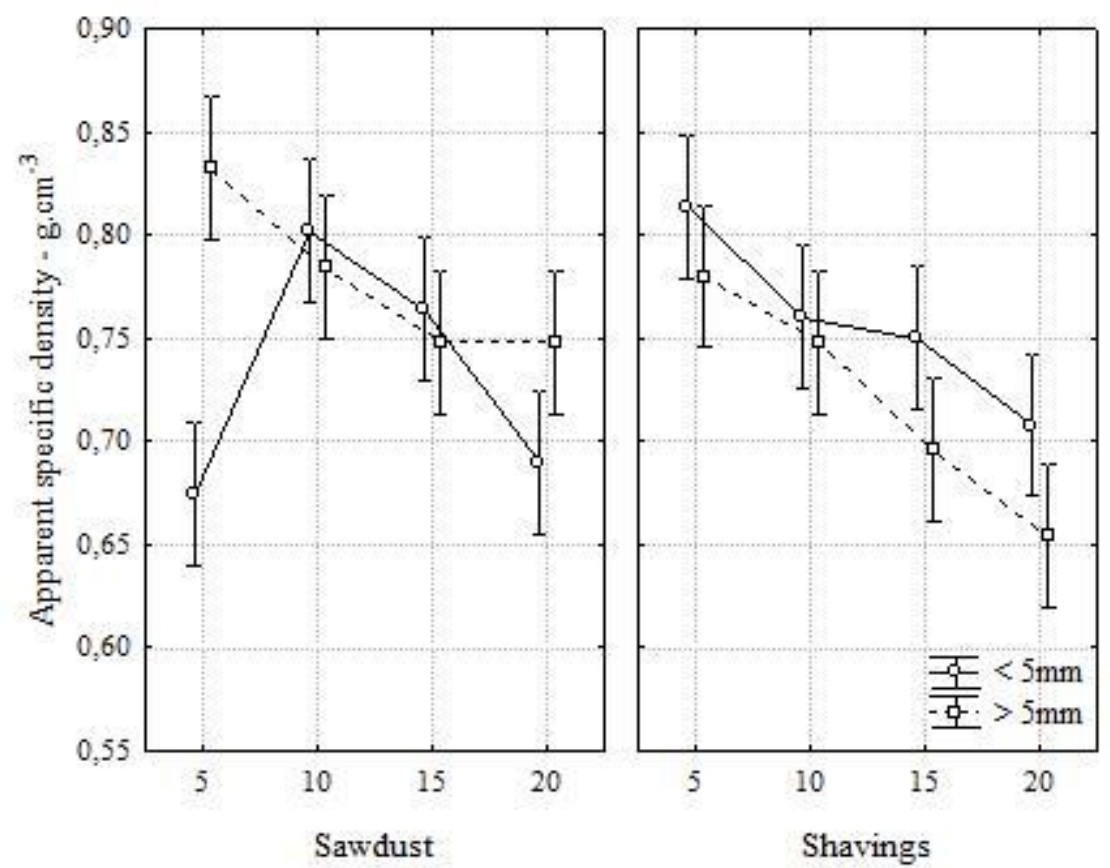

Means along the same bar do not differ significantly from each other by the Tukey test at $95 \%$ probability.

Figure 1. Comparison between the apparent specific density according to the proportion of wood waste of Pinus spp and the particle sizes of the charcoal fines.

Figura 1. Comparação entre a massa específica aparente em função da proporção dos resíduos da madeira de Pinus spp e granulometria da moinha de carvão vegetal.
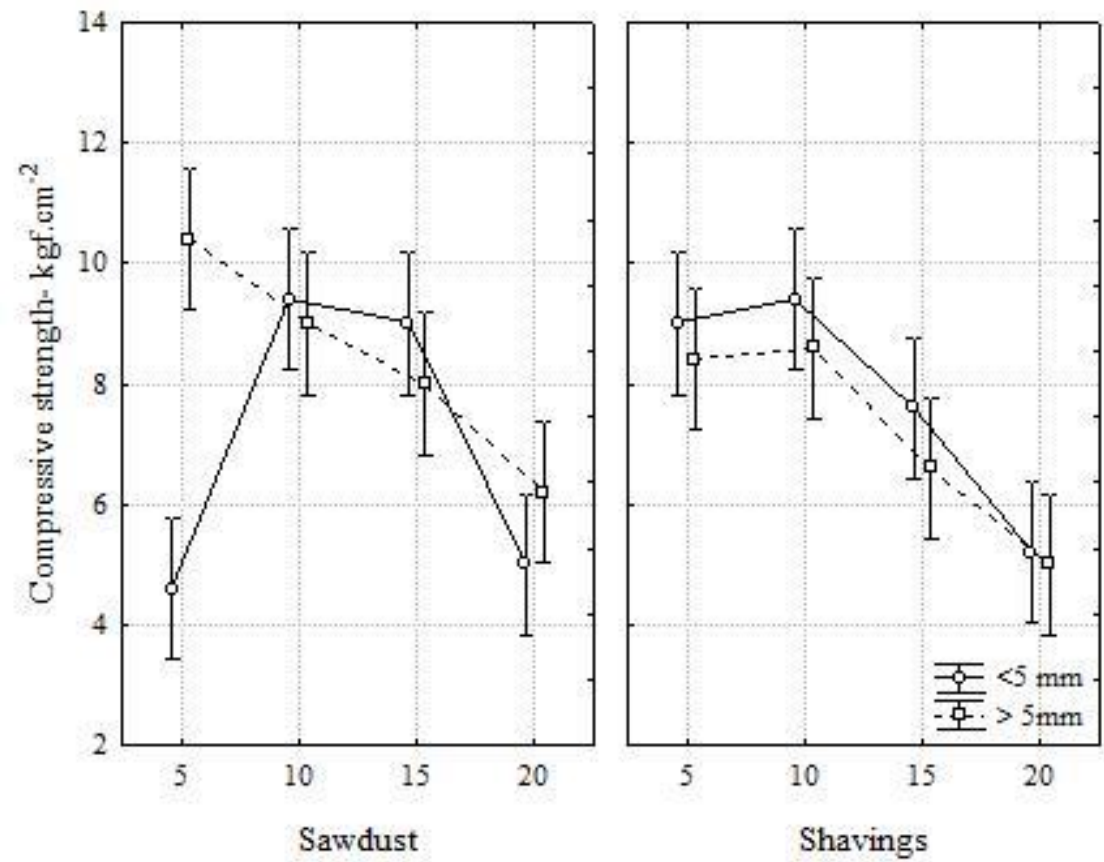

Means along the same bar do not differ significantly from each other by the Tukey test at $95 \%$ probability.

Figure 2. Comparison between the compressive strength of the briquettes according to the type of wood waste of Pinus spp, the proportion of the waste, and the particle sizes of the charcoal fines.

Figura 2. Comparação entre a resistência à compressão dos briquetes em função do tipo de resíduo da madeira de Pinus spp, proporção do resíduo e granulometria da moinha de carvão.

FLORESTA, Curitiba, PR, v. 48, n. 4, p. 513-522, out/dez. 2018

Vieira. A. T. O. et.al.

ISSN eletrônico 1982-4688

DOI: $10.5380 /$ rf.v48i4.55028 
Tables 4 and 5 show, respectively, the Kruskal-Wallis and Mann Whitney test results, applied for the analysis of the friability indexes of the briquettes after the friability test.

Table 4. Friability index after friability test according to the proportion of wood waste of Pinus spp in the composition of the briquettes.

Tabela 4. Índice de friabilidade após o teste de tamboramento em função da proporção de resíduo da madeira de Pinus spp na composição dos briquetes.

\begin{tabular}{ccc}
\hline & Resistance to Friability (ranks) & \\
\hline Waste Pinus spp (\%) & Rank sum & Mean (\%) \\
\hline 5 & $600^{\mathrm{bc}}$ & $30.0^{\mathrm{bc}}$ \\
10 & $502^{\mathrm{c}}$ & $25.1^{\mathrm{c}}$ \\
15 & $925^{\mathrm{ab}}$ & $46.3^{\mathrm{ab}}$ \\
20 & $1213^{\mathrm{a}}$ & $60.7^{\mathrm{a}}$ \\
\hline
\end{tabular}

Different lowercase letters in the column indicate significant differences between the means of the treatments by the Kruskal-Wallis test at the $95 \%$ probability level.

Table 5. Friability index according to the type of wood waste of Pinus spp and the particle sizes of the charcoal fines in the composition of the briquettes.

Tabela 5. Índice de friabilidade em função do tipo do resíduo da madeira de Pinus spp e da granulometria da moinha do carvão vegetal na composição dos briquetes.

\begin{tabular}{ccc}
\hline & Resistance to Friability (ranks) & Mean $(\%)$ \\
\hline Waste Pinus spp & Rank sum & $76.7^{\mathrm{a}}$ \\
\hline Sawdust & $1534.5^{\mathrm{a}}$ & $85.3^{\mathrm{a}}$ \\
Shavings & $1705.5^{\mathrm{a}}$ & Mean $(\%)$ \\
\hline Average particle size $(\mathbf{m m})$ & Rank sum & $86.6^{\mathrm{a}}$ \\
\hline 55 & $1732.5^{\mathrm{a}}$ & $75.4^{\mathrm{a}}$ \\
\hline
\end{tabular}

Different lowercase letters in the column indicate significant differences between the means of the treatments by the Mann-Whitney test at the $95 \%$ probability level.

\section{DISCUSSION}

The sharp reduction in the mean apparent specific mass of the briquettes can be attributed to the occurrence of partial failures in the homogenization or during the pressing of the analyzed materials (Figure 1). This observation corroborates the results observed by Dias Júnior et al. (2016), which analyzed briquettes produced from charcoal fines, bamboo waste, and pulp and paper waste (dregs). In addition, it can be assumed that the compression force applied to the residues allowed for less compaction and, consequently, favored the occurrence of greater porosity for the briquettes and, thus, lower mass per unit volume.

Except for the treatment in which 5\% sawdust was included in the charcoal grinder with a mean particle size of less than $5 \mathrm{~mm}$, it can be seen that there was a tendency to decrease the apparent specific masses as the proportion of the wood residues of Pinus spp increased in the composition of briquettes. Possibly, the inclusion of higher percentages of the residues was responsible for the decrease of the apparent specific mass of the briquettes because the wood of Pinus spp is usually of low density. Within the respective proportions of the residues, the briquettes produced from shavings and sawdust of charcoal with a mean particle size $>5 \mathrm{~mm}$ presented the lowest values of apparent specific mass, as compared with the briquettes obtained from the other treatments. Again, the exception was represented by the briquettes consisting of charcoal fines with particle size $<5 \mathrm{~mm}$, that was mixed at the 5\% sawdust proportion. The hypothesis associated to this behavior is related to the fact that smaller particle sizes favors the arrangement of the particles, favoring the compression process and, consequently, higher values of specific apparent mass (DIAS JÚNIOR et al., 2014).

Analyzing the physical properties of briquettes produced with charcoal fines mixed with bamboo residues under seven different formulations, Dias Júnior et al. (2014) found specific apparent masses for briquettes ranging from $0.30 \mathrm{~g} . \mathrm{cm}^{-3}$ (50\% charcoal and $50 \%$ bamboo residues) to $0.85 \mathrm{~g} . \mathrm{cm}^{-3}$ (100\% charcoal fines). However, the specific mass obtained by Jacinto et al. (2016) was, on average, $1.14 \mathrm{~g} . \mathrm{cm}^{-3}$ for briquettes produced from material derived from jatropha straws in different formulations. In the present study, the apparent specific masses of the briquettes remained closer to the second level, as observed by the first authors. Quirino et al. (2012) point out that, in general, briquettes are produced without an internal homogeneous density distribution, which implies low mechanical resistance and dimensional stability. 
In the compressive strength test, the composition of the wood shavings was evaluated. The briquettes produced with charcoal fines with particle size $<5 \mathrm{~mm}$ presented the greatest resistance, probably due to the best arrangement of these particles and the higher densities previously reported. As can be seen in Figure 2, such behavior was less pronounced in the case of sawdust. In general, the results for compressive strength of briquettes are associated with their respective apparent specific masses (Table 2). Thus, under the conditions in which the present research was carried out, there are indications of a positive correlation between the resistance of the briquettes to compression and their respective apparent specific masses.

Conversely, for the reasons mentioned earlier, Dias Júnior et al. (2016) detected a negative correlation between the compressive strengths and the apparent specific masses of briquettes produced with charcoal fines and bamboo residues. Araújo et al. (2016) highlight the relationship between these variables, as well as the influence of compression pressure on the briquettes properties. In addition, some references indicate that, in the briquetting process, materials of greater particle sizes result in briquettes with better physico-mechanical properties when compared, for example, with briquettes produced with materials of smaller particle sizes (JERSERSKA et al., 2014).

In this study, the average values found for the compressive strength of the briquettes varied from $4.6 \mathrm{kgf} . \mathrm{cm}^{-2}$ to $10.4 \mathrm{kgf} . \mathrm{cm}^{-2}$. The highest values, most of the time, coincided with the lower proportions of wood residues of Pinus spp, due to low wood density. In the research conducted by Quirino et al. (2012), these values ranged from $13.68 \mathrm{kgf.cm}$ to $48.12 \mathrm{kgf} . \mathrm{cm}^{-2}$. and the highest values for briquettes were produced with higher proportions of fine sawdust from Eucalyptus sp, compacted under a pressure of $120 \mathrm{kgf} . \mathrm{cm}^{-2}$ and temperature of $200^{\circ} \mathrm{C}$. These variations can be attributed to the differences between the processes, equipment, molds, loads, and pressing times, as well as between the morphology of the particles and the physical and mechanical properties of the residues used (ARAÚJO et al., 2016, WU et al., 2018). According to Wang et al. (2017), the maximum resistance is achieved through compression temperatures around $220^{\circ} \mathrm{C}$, another aspect that may also explain the results obtained in this research.

For iron and steel purposes, Quirino and Brito (1991) have suggested briquettes with compressive strengths around $70 \mathrm{kgf.cm}{ }^{-2}$. For briquettes with low compressive strengths, some authors recommend treatments or processing that do not require excessive handling, transport over long distances, and storage for long periods of time, and it is interesting to use them as close to the production site as possible. In this context, they mention the direct burning in furnaces of stills, grain dryers, potteries, and ceramics, among other uses (DIAS JÚNIOR et al., 2014; BOASIAKO; ACHEAMPONG, 2016; DIAS JÚNIOR et al., 2016).

The friability indexes of the briquettes decreased as the wood residue proportions of Pinus spp were increased in their composition (Table 4). Similarly, Boasiako and Acheampong (2016) analyzed the friability of briquettes produced with wood sawdust of species of different densities and found that with the increase in the proportion of the wood brighter in the briquettes composition, there was a decrease in the friability two briquettes. The authors attributed this result to the good conformation between the sawdust particles of higher density, which when arranged in a more organized way, generating more resistant briquettes.

According to Table 5, the friability indexes of the briquettes were not significantly affected by the type of biomass (sawdust or wood shavings of Pinus spp) and by the average particle sizes of the charcoal fines. In addition, the studied variables residues and particle sizes are presented as technically feasible alternatives for the production of briquettes when considering the fine generation aspect. For Martins et al. (2016), Bamgboye and Bolufawi (2009), and Boasiako and Acheampong (2016), it is possible to reduce brittle friability by decreasing the humidity or increasing the compaction pressure. This is because these factors have a greater influence on the molecular interactions observed in their structures.

\section{CONCLUSION}

- The briquettes produced with charcoal fines, mixed with 5 and $10 \%$ of the residues of the wood of Pinus spp (sawdust or shavings), present a higher apparent specific mass and greater resistance to compression. Experimental results have also shown that briquettes produced under these conditions are less friable.

- The use of the charcoal fines, combined with sawdust or shavings of Pinus spp, was a technically feasible alternative for the production of briquettes, presenting good physical and mechanical properties.

- Further studies are recommended for energy assessment and reactivity tests (CRI and CSR) of briquettes produced for steel purposes. However, when the product is intended for use in the cooking of food, qualitativequantitative studies of the gases from combustion are recommended.

FLORESTA, Curitiba, PR, v. 48, n. 4, p. 513-522, out/dez. 2018 


\section{REFERENCES}

ARAÚJO, S.; VILAS BOAS, M. A.; NEIVA, D. M.; CARNEIRO, A. C. O.; VITAL, B. R.; BREGUEZ, M.; PEREIRA, H. Effect of a mild torrefaction for production of eucalypt wood briquettes under different compression pressures. Biomass and Bioenergy, Amsterdã, v. 90, p. 181-186, 2016.

ASSOCIAÇÃO BRASILEIRA DE NORMAS TÉCNICAS - NBR 8293: Determinação de umidade. Rio de Janeiro, 1983. 6p.

ASSOCIAÇÃO BRASILEIRA DE NORMAS TÉCNICAS - NBR 8629: Análise granulométrica. Rio de Janeiro, 1984. 13p.

ASSOCIAÇÃO BRASILEIRA DE NORMAS TÉCNICAS - NBR 9165: Determinação da densidade relativa aparente, relativa verdadeira e porosidade.Rio de Janeiro, 1982. 15p.

BAMGBOYE, A. L.; BOLUFAWI, S. J. Physical characteristics of briquettes from Guinea Corn (sorghum bicolor) residue. Agriculture Engineering Internacional CIGR E-Journal, Beijing, v. 21, p. 1-10, 2009.

BOASIAKO, C. A.; ACHEAMPONG, B. B. Strength properties and calorific values of sawdust-briquettes as wood-residue energy generation source from tropical hardwoods of different densities. Biomass and Bioenergy, Amsterdam, v. 85, p.144-152, 2016.

BRAND, M. A. Energia de biomassa florestal. Rio de Janeiro, RJ: Interciência, 2010.114 p.

BRASIL. Ministério de Minas e Energia. Balanço Energético Nacional - BEN. Rio de Janeiro: Empresa de Pesquisa Energética, 2017. EPE, 296p. Disponível em: https://ben.epe.gov.br/downloads/Relatorio_Final_BEN_2017.pdf. Acessado em: 08 de mar. 2018.

COELHO JÚNIOR, L. M; REZENDE, J. L. P.; OLIVEIRA, A. D. Concentração das exportações mundiais de produtos florestais. Ciência Florestal, Santa Maria, v. 23, n. 4, p. 691-701, 2013.

DIAS JÚNIOR, A. F.; ANDRADE, A. M.; COSTA JÚNIOR, D. S. Caracterização de briquetes produzidos com resíduos agroflorestais. Pesquisa Florestal Brasileira, Colombo, v. 34, n. 79, p. 225-234, 2014.

DIAS JÚNIOR, A. F.; ANDRADE, A. M. de; CARVALHO, A. M.; BENICIO, E. L; BRITO, J. O. Produção de briquetes de moinha de carvão vegetal e resíduos lignocelulósicos visando uso bioenergético. Scientia Forestalis, Piracicaba, v. 44, n.110, p. 453-462, 2016.

JACINTO, R. C.; BRAND, M. A.; RIOS, P. D.; CUNHA, A. B.; ALLEGRETTI, G. Análise da qualidade energética da falha de pinhão para a produção de briquetes. Scientia Forestalis, Piracicaba, v. 44, n. 112, p. 821829, 2016.

JEZERSKAA, L.; ZAJONCA, O.; ROZBROJA, J.; VYLETĚLEKA, J.; ZEGZULKAA, J. Research on effect of spruce sawdust with added starch on flowability and pelletization of the material. IERIA Procedia, Kabacan, v. 8 , p. 154-163, 2014.

KALIYAN, N.; R. MOREY, V. Natural binders and solid bridge type binding mechanisms in briquettes and pellets made from corn stover and switchgrass. Bioresource Technology, Amsterdam, v. 101, p.1082-1090, 2010.

MARTINS, M. P.; BENICIO, E. L.; DIAS JÚNIOR, A. F.; ALMEIDA, R. B.; CARVALHO, A. M.; YAMAJI, F. M. Produção e avaliação de briquetes de finos de carvão vegetal compactados com resíduo celulósico proveniente da indústria de papel e celulose. Revista Árvore, Viçosa, v. 40, n. 1, p. 173-180, 2016.

PAULA, L. E. R.; TRUGILHO, P. F.; REZENDE, R. N.; ASSIS, C. O.; BALIZA, A. E. R. Produção e avaliação de briquetes de resíduos lignocelulósicos. Pesquisa Florestal Brasileira, Colombo, v. 31, n. 61, p. 103-112, 2011.

PEREIRA, F. A.; CARNEIRO, A. C.O.; VITAL, B. R.; DELlA LUCIA, R. M.; PATRICIO JÚNIOR, W.; BIANCHE, J. J. Propriedades físico-químicas de briquetes aglutinados com adesivo de silicato de sódio. Floresta e Ambiente, Seropédica, v. 16, n. 1, p. 23-29, 2009.

PROTÁSSIO, T. P.; ALVES, I. C. N.; TRUGILHO, P. F.; SILVA, V. O.; BALIZA, A. E. R. Compactação da biomassa vegetal visando a produção de biocombustíveis sólidos. Pesquisa Florestal Brasileira, Colombo, v. 31, n. 68 , p. 273-283, 2011.

PROTÁSIO, T. P.; BUFALINO, L.; MENDES, R. F.; RIBEIRO, M.X.; TRUGILHO, P. F.; LEITE, E. R. Torrefação e carbonização de briquetes de resíduos do processamento dos grãos de café. Revista Brasileira de 
Engenharia Agrícola e Ambiental, Campina Grande, v. 16, n. 11, p.1252-1258, 2012.

QUIRINO, W. F.; BRITO, J. O. Características e índice de combustão de briquetes de carvão vegetal. Brasília, DF: LPF/IBAMA, 1991. 18 p. (Série Técnica, 13).

QUIRINO, W. F.; PINHA, I. V. O.; MOREIRA, A. C. O.; SOUZA, F.; TOMAZELLO FILHO, M. Densitometria de raios x na análise da qualidade de briquetes de resíduos de madeira. Scientia Forestalis, Piracicaba, v. 40, n. 96, p. 525-36, 2012.

SANTIAGO, A. R.; ANDRADE, A. M. de. Carbonização de resíduos do processamento mecânico da madeira de eucalipto. Ciência Florestal, Santa Maria, v. 15, n.1, p.1-7, 2005.

WANG, Q.; HAN, K.; GAO, J.; LI, H.; LU, C. The pyrolysis of biomass briquettes: Effect of pyrolysis temperature and phosphorus additives on the quality and combustion of biochar briquettes. Fuel, Amsterdam, v. 199, p. 488496, 2017.

WU, S.; ZHANG, S.; WANG, C.; MU, C.; HUANG, X. High-strength charcoal briquette preparation from hydrothermal pretreated biomass wastes. Fuel Processing Technology, Amsterdam, v. 171, p. 293-300, 2018. 
FLORESTA, Curitiba, PR, v. 48, n. 4, p. 513-522, out/dez.2018 